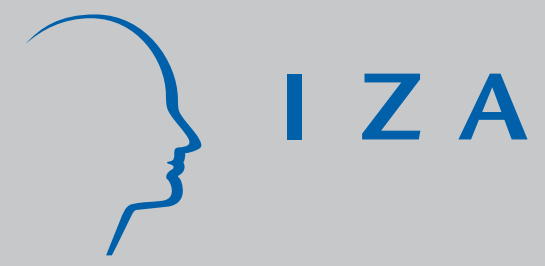

IZA DP No. 8414

The Sources of the Gender Gap in Economics Enrolment

Mirco Tonin

Jackline Wahba

August 2014

Forschungsinstitut

zur Zukunft der Arbeit

Institute for the Study

of Labor 


\title{
The Sources of the Gender Gap in Economics Enrolment
}

\author{
Mirco Tonin \\ University of Southampton, \\ CEU, CESifo and IZA \\ Jackline Wahba \\ University of Southampton \\ and IZA
}
Discussion Paper No. 8414
August 2014

\author{
IZA \\ P.O. Box 7240 \\ 53072 Bonn \\ Germany \\ Phone: +49-228-3894-0 \\ Fax: +49-228-3894-180 \\ E-mail: iza@iza.org
}

\begin{abstract}
Any opinions expressed here are those of the author(s) and not those of IZA. Research published in this series may include views on policy, but the institute itself takes no institutional policy positions. The IZA research network is committed to the IZA Guiding Principles of Research Integrity.

The Institute for the Study of Labor (IZA) in Bonn is a local and virtual international research center and a place of communication between science, politics and business. IZA is an independent nonprofit organization supported by Deutsche Post Foundation. The center is associated with the University of Bonn and offers a stimulating research environment through its international network, workshops and conferences, data service, project support, research visits and doctoral program. IZA engages in (i) original and internationally competitive research in all fields of labor economics, (ii) development of policy concepts, and (iii) dissemination of research results and concepts to the interested public.
\end{abstract}

IZA Discussion Papers often represent preliminary work and are circulated to encourage discussion. Citation of such a paper should account for its provisional character. A revised version may be available directly from the author. 


\section{ABSTRACT}

\section{The Sources of the Gender Gap in Economics Enrolment}

In many countries there is a considerable gender gap in enrolment for a bachelor's degree in Economics, arguably an important stepping stone towards positions of influence in policy making and occupations paying relatively high wages. We investigate the sources of this gap by looking in detail at the university admission process in the UK. We use a 50 percent random sample of administrative data covering all university applications in 2008 and find no evidence of universities discriminating against female applicants. What we find is that girls are less likely to apply for a bachelor's degree in Economics to start with, even if once they apply their likelihood of enroling is the same as for boys. Girls are less likely to study Maths in high school and this may deter them from applying to study Economics at the university level. However, even among those who have studied Maths, females are less likely to apply than males, suggesting that differences in the choice of $A$ level subjects cannot explain the whole gap.

JEL Classification: $\quad 121,123,128, \mathrm{~J} 24$

Keywords: education, economics, gender, discrimination, pay gap

Corresponding author:

Mirco Tonin

Economics Department

School of Social Sciences

University of Southampton

Southampton SO17 1BJ

United Kingdom

E-mail:m.tonin@soton.ac.uk

\footnotetext{
* We would like to thank the Editors, Alessandra Casarico and Paola Profeta, and two anonymous reviewers for thoughtful comments. We would also like to thank participants at the 2013 CESifo Venice Summer Institute workshop on "The Determinants of Gender Gaps: Institutional Design and Historical Factors" and to acknowledge CESifo support. We use administrative data from UCAS (Universities and Colleges Admissions Service). UCAS cannot accept responsibility for any inferences or conclusions derived from the data by third parties.
} 


\section{Introduction}

In October 2013, President Obama nominated Janet L. Yellen to lead the Federal Reserve. After the Senate confirmation, she became the first woman to lead the US central bank. Janet L. Yellen graduated from Brown University with a degree in Economics in 1967, a period when very few women majored in Economics. Indeed, the proportion of Economics B.A.'s awarded to women in the US was just 11 percent in 1970 (Kahn, 1995). Since then, women's college-enrolment and graduation rates relative to males have significantly increased (Goldin et al., 2006). There are however big gender differences in terms of subject of study. For the subject of Economics, for instance, according to US education statistics, in 1991-92 women received only 30 percent of the bachelor's degrees in Economics against a 54 percent for bachelor's degrees in all fields (Dynan and Rouse, 2010). The situation in the UK is similar: using administrative data for enrolment in 2008, we find that females represent 57 percent of those enroling for undergraduate courses in all fields, but only 27 percent in Economics.

Why is there such a big gender gap in enrolment for a bachelor's degree in Economics? In this paper we contribute to answering this question by looking in detail at the application process to higher education courses in the UK, using administrative data from UCAS (Universities and Colleges Admissions Service), the organization responsible for managing these applications. One possibility is that female students choose different courses at high school than males and, thus, are not prepared to meet the requirements to enrol into an Economics course when applying to college (Turner and Bowen, 1998). In practice, given the Maths requirements in Economics, this would be the case if girls took less Maths courses than boys at high school. Another possibility is that female applicants are somehow discriminated against in the application process $^{1}$, either because they are perceived as less competent in the field of Economics ${ }^{2}$, or because they are less likely to accept if an offer is made, possibly because Economics is lower in their (unobserved by the admission officer) ranking of subjects. A further possibility is that, even if girls are as prepared as boys and are not discriminated against in the application process, they still choose not to apply to an Economics degree, either because of lower labour market prospects or because of different tastes or for other reasons. ${ }^{3}$ Our data allow us to see where in the application process the gender gap in

\footnotetext{
${ }^{1}$ In the field of medicine, a report by the British Medical Association Equal Opportunities Committee (2009, p. 65) comments how "[t]here have been anecdotal suggestions that some medical schools may be trying to restrict the overall numbers of female students entering medical school, in order to prevent gender imbalance in the medical workforce of the future."

${ }^{2}$ Moss-Racusin et al. (2012) find that science faculty members from research-intensive universities exhibit a bias against female undergraduate students, rating male applicants for a laboratory manager position as significantly more competent and hireable than the (identical) female applicants.

${ }^{3}$ One additional possibility, for instance, is that Economics is relatively riskier than other disciplines, either in
} 
Economics emerges, i.e. how big the differences between genders are at the application stage, or in offers made by universities, or at the stage of acceptance of these offers by students. Moreover, we have detailed information about the qualifications obtained by students in high school (AS and A levels) and school characteristics, as well as some socio-demographic information (gender, age, ethnic group, parental socioeconomic background). We can then investigate whether admission practices by universities mitigate or exacerbate the gender gap, or whether women are less likely to accept offers made by universities than men, or whether the difference in enrolment between genders arises entirely at the application stage, with less women applying for Economics courses. This type of knowledge is needed to guide any policy that may be addressed at rebalancing the gender composition in Economics.

We believe that differences among males and females in enrolment for bachelor's degrees in Economics are of particular importance, and thus may warrant a policy intervention, for two sets of reasons, related to policy making and labour market outcomes. The first set of reasons relates to the fact that economists have generally an influential role in policy making, either as academics, consultants or policy analysts working in think tanks, ministries, central banks, or international organizations like the IMF or the World Bank. Several studies have shown how males and females have different policy preferences. For instance, Burgoon and Hiscox (2009) find that "women are substantially less likely than men to support increasing trade with foreign nations", even after controlling for differences in occupation and political values. A possible explanation proposed by the authors is related to gender differences in exposure to economic ideas and information. This however cannot be the explanation in the study by May, McGarvey and Whaples (2013) that focuses on members of the American Economic Association and finds significant differences between male and female economists for a large set of policies. For instance, male economists express greater opposition to mandating that employers provide health insurance than female economists and express greater support for the use of vouchers in education. Male economists are generally more likely to see the costs associated with government intervention and, for instance, are more likely to see a loss of employment from raising the minimum wage. Looking at policy actions rather than opinions, Chattopadhyay and Duflo (2004) exploit the fact that in India the position of Village Council head was randomly reserved for a woman in some villages to show that the gender of the head affects the types of public goods provided, with heads biasing investment in infrastructures towards the needs of their own gender. Also, Clots-Figueras (2011) finds that politicians' gender affects policy in the context of Indian State Legislatures, and Svaleryd (2009)

terms of the likelihood of completing the degree or in terms of career. Then, differences in enrolment could emerge if females are less risk tolerant than males (see, however, Filippin and Crosetto, 2014, for a recent survey challenging this view on gender differences in risk preferences). 
finds a gender effect in policies implemented by Swedish local councils ${ }^{4}$. If indeed women and men have different policy preferences and these preferences contribute to shape policies, then the gender of those making policy is relevant. ${ }^{5}$ As an Economics degree gives access to many positions related to policy making, this makes the gender gap in Economics enrolment particularly important to study. Just as an example, the first female cabinet minister in Sweden, Karin Kock, was also the second one to complete a Ph.D. in Economics ${ }^{6}$ and the first given the title of Professor in Economics in her country (Jonung and Stahlberg, 2012).

Enrolment in Economics is also relevant with regards to women's economic outcomes and, in particular, to the gender pay gap. Different degrees lead to different occupations and different occupations lead to different earnings. Indeed, the observed occupational segregation by gender accounts for a substantial portion of the overall gender earnings gap (Gunderson, 1989). Machin and Puhani (2003) look specifically at the impact of subject of degree on the gender wage differential. They use UK and German Labour Force Surveys for 1996, where graduates were asked to report the subject of study of their degree according to a detailed classification. They observe very marked gender differences in degree subject in both countries, with males prevalent in subjects like Engineering and Physical Sciences, while females have a much larger share of graduates in Humanities, Creative Arts, and Education. They find that including detailed degree subject in Mincerian wage equations contributes to explaining wage differentials between male and female graduates in both countries in a statistically and economically significant way. For the US case, McDonald and Thorntonas (2007) show that "as much as 95 percent of the overall gender gap in starting salary offers can be explained by differences in college majors selected". Given that Economics is one of the subjects associated with relatively high average earnings (O'Leary and Sloane, 2005), then lower enrolment by females into Economics is a contributing factor behind the gender pay gap.

In our empirical analysis we find no evidence that females are less likely to accept an offer for a bachelor's degree in Economics, thus indicating that, conditional on applying, Economics is not lower in the ranking for females than for males. We also do not find evidence of universities discriminating against female applicants. What we find is that girls are less likely to apply for a bachelor's degree in Economics to start with, while they are over-represented in certain degrees that are associated with more female concentrated occupations such as Nursing and Education. Moreover, girls are less likely to have A levels in Maths than boys, and this could represent an

\footnotetext{
${ }^{4}$ Other papers like Ferreira and Gyourko (2014) and Campa (2011) fail to find a gender effect on policy.

${ }^{5}$ In an electoral contest, this is the case in a probabilistic voting model with partisan politicians, while it would not be the case with Downsian electoral competition (see Persson and Tabellini, 2002, for a general overview).

${ }^{6}$ The first was Margit Cassel, daughter of the economist Gustav Cassel.
} 
impediment to apply for an Economics degree. However, even among those who have studied Maths, females are less likely to apply for an Economics degree than males, suggesting that differences in the choice of A level subjects cannot explain the whole gap. In the conclusion, we will discuss some of the possible explanations for these differences between genders.

The rest of the paper is organized as follows. Next section presents the institutional context. The third section introduces the data, while the fourth section presents the analysis. The last section concludes.

\section{Institutional Context}

All applications to UK universities for full-time undergraduate courses take place through the Universities and Colleges Admissions Service (UCAS). The basic application procedure is as follows (a more detailed description is provided in the following section). Applicants apply to their institutions of choice via UCAS who then collates the offers (conditional or unconditional) or rejections from these institutions. Given the offers received, the applicants then pick their firm and insurance choice. UCAS then collects exam results from the awarding bodies in the summer and transfer these to the institutions. Applicants are then accepted or not depending on whether they have met their conditions or not.

From the 2008 entry onwards, an applicant can apply on-line through UCAS for a maximum of five university courses, four in the case of medical applications and only one course at either Oxford University or University of Cambridge. There are no restrictions on course-university combinations that can be applied for. The UCAS website contains detailed information on the application system, courses and universities.

\subsection{Application Process}

In each annual round, applications are received between September and mid-January (or midOctober in the case of Oxford and Cambridge) of the calendar year prior to university entry. All applicants intending to proceed from high school to university submit their application form prior to the completion of their high school studies and hence without knowledge of their final high school grades ("A levels", for applicants from England, Wales and Northern Ireland, and "Highers" for Scottish students, see below for details). The application, however, includes predicted grades which are provided by the applicant's school based on previous performance and AS marks. Once 
an application is submitted to UCAS, the relevant university can access it online, but will not see where else the applicant has applied to, before the applicant has replied to their offer. When evaluating an application, information about the applicant's identity (name) and gender is available to admission officers, while other information (like ethnicity) is provided only after the institution has made a decision on the application. The university's response to an application can either be a rejection, an unconditional offer, or a conditional offer, subject to the applicant achieving certain minimum grades in his or her A levels.

Applicants can decide to decline an offer, accept it as a "Firm" or as an "Insurance" place. If an applicant firmly accepts an offer, this becomes his or her preferred choice out of all the offers received. Applicants can only make this choice once. By accepting an unconditional offer the applicant is agreeing to attend the course at that university and must decline all other offers, whilst accepting a conditional offer is agreeing to attending the course at that university if the conditions of the offer are met. In this case, an applicant can accept another offer as an insurance choice. The offer accepted as an insurance choice can be conditional or unconditional and acts as a back-up to the firm choice, so if the conditions for the firm choice are not met, but the conditions (if any) for the insurance choice are met, the applicant is committed to that course.

Applicants who have applied through UCAS and are not holding any offer after this first stage, may be able to apply for another course through "Extra", between the end of February and the end of June. Once the A level results are released, universities confirm or decline their offers through the UCAS system. Finally, "Clearing" is used by applicants who have not managed to secure a place at any university for the current year. This system is used towards the end of the academic cycle (August/September). In this case, both the applicant and the institution to which the application has been made have full information about grades achieved. More than 30,000 applicants gain a place through Clearing every year.

In 2006/07, fees up to $£ 3,000$ per year were introduced for all students, regardless of background. These fees are deferrable until after graduation using government subsidized loans. Maintenance grants, which had been reintroduced in 2004 for the poorest students, were also increased substantially at this time. In 2012, after an independent review of tuition fee policy, the UK's coalition government increased the cap on tuition fees to $£ 9,000$ per year. 


\section{$2.2 \quad$ A Levels}

AS and A levels are the traditional qualifications offered by schools and colleges for 16-19 years old. AS levels can be taken as a stand-alone qualification, or as the first part of an A level course. AS levels are completed at the end of Year 12 (the old 'Lower Sixth' year). A2 exams and coursework are added on to an AS level at the end of Year 13 (the old 'Upper Sixth' year), bringing it up to A level standard. Most pupils take four subjects in Year 12. After AS level exams they drop one subject, and continue the other three through Year 13 to complete A levels.

\section{Data}

Our analysis is based on administrative data from UCAS. We have a 50 percent random sample of all UCAS applications in the 2008 cycle for UK domiciled applicants totalling 230,722 applicants and 959,915 applications. UCAS data provide rich information on applicants, their applications, offers, acceptances and refusals into courses. In particular, in terms of socio-demographic characteristics of the applicants, UCAS data include age, ethnicity, gender, socioeconomic status, and region. We also have information about the type of high school attended (e.g. grammar, independent) and the region where it is located, as well as about qualifications obtained at high school (A and AS levels) and about the so called "tariff", a points system used to summarize achievement in a numerical and comparable format. We also have detailed information about the university application process, observing all applications (subject, course type, institution, route - e.g. main, extra, clearing), offers, and acceptances.

Our focus in on the process that leads students to enrol in Economics. Although we look at final acceptance and do not observe actual enrolment, in aggregate the number of accepted applicants is very close to the number of students who actually enrol. Therefore, in the rest of the paper we refer to final acceptance as enrolment. Also, we restrict our sample to those who enroled at university, thus excluding those who applied to at least one course, but finally did not enrol. This leaves us with 185,002 students who enrol at university.

It is important to note that applicants are asked to record their ethnic origin on the UCAS application form. Provision of this information is voluntary and it is not passed to institutions until after the selection process. Also, UCAS assigns socioeconomic status based on an applicant's parental occupation (based on the Standard Occupational Classification 2000). This information is not passed to institutions until after the selection process. 
Table 1 presents the characteristics of all UCAS applicants who enrol on a university degree $(185,002)$ relative to those who enrol on an Economics degree $(2,373)$. Interestingly, 57 percent of all students who enrol for university degrees are females, whilst for Economics degrees, only about a quarter are females (27 percent). This highlights the gender gap in Economics university enrolment. Not surprisingly, 95 percent of those enroling in Economics are younger than 20 years of age, whilst there are more mature students enroling for other degrees. Also, only 63 percent of those enroled into Economics are from white ethnic background compared to 79 percent for all degrees. Furthermore, those who enrol to study Economics seem to be more likely to come from more privileged socioeconomic backgrounds and from independent schools compared to the general population of those enroling to university. Also, there is evidence that those who go on to study Economics at university are more likely to have done Economics and Maths at A level. Economics attract high ability students as evident in their scores (tariff) being much higher than the average. Finally, half of the Economics students study in one of the top 20 Universities in the UK (refereed to as the Russell group).

Table 1 has shown that females are less likely to be enroled on an Economics degree than males. Next, we investigate the gender gap throughout the application process. In particular, in Table 2, we present some descriptive statistics by gender. Indeed, the first significant difference is that, among those who enrol at university, females (1.16 percent) are less likely compared to males (3.78 percent) to apply to Economics to start with. However, conditional on applying, there is no evidence from the descriptive statistics that there is a gender gap in university offers, for both conditional and unconditional ones (86\%). Likewise, conditional on getting an offer, there is no gender difference in the applicants' acceptance rate, whether firm or insurance, for Economics degrees. In terms of subject' choice at A levels, for the general population of those enroling at university there is evidence of a gender gap when it comes to the choice of Maths at A level, as females are less likely to do Maths (10 percent compared to 19 percent among males). Interestingly though, those females who apply to read Economics, tend to have a stronger Maths background (49 percent compared to 43 percent) and higher average scores than males applying for Economics degrees.

\section{Analysis}

In order to better understand the gender gap in Economics, we estimate the probability of university enrolment into Economics degrees as opposed to enrolment into other degrees. Table 3 presents the 
marginal effects showing that females are less likely to enrol into an Economics degree even after controlling for individual characteristics (column 1), and adding as controls school type (column 2) and region (column 3). The gap drops but persists when we control for the subject choice at A level, and in particular Maths (column 4), and further drops if we control for Economics A level (column 5). Adding a measure of the quality of students measured using the overall A level score, tariff, does not make a big difference (column 6). Also, adding dummies for the most popular subject combinations at A level involving Math, Science, Business, Economics, and English (column 7) does not make a difference. Thus, a significant portion of the gender gap in Economics enrolment is explained by the choice of A level subjects, in particular Maths, and, not surprisingly, Economics.

To unravel the cause of this gap in Economics enrolment, in Table 4, we estimate the gap at each stage of the application process, conditional on "having passed" the previous stage. First, in column (1), we estimate the probability of applying for an Economics degree and find that females are less likely than males to apply for Economics degrees, after controlling for individual and school characteristics and region. This suggests that Economics is not as attractive for females, who tend instead to be over-represented in certain degrees that are associated with more female concentrated occupations such as Nursing and Education (see Table 6 further on). Secondly, in columns (2)-(5), we estimate the probability of receiving an offer conditional on applying for an Economics degree at university. We find no significant difference between females and males either when we distinguish between conditional (column 2) and unconditional (column 3) offers, or when we aggregate the two (column 4), even after adding further controls for score and A-level subjects (column 5), thus comparing applicants that are very similar from the point of view of admission officers. ${ }^{7}$ This suggests that universities do not discriminate against females when making their offers.

Examining the gap at the stage of the reply by applicants to a university offer (columns 6 and 7), the estimates show that gender does not matter when examining the probability of an applicant who has an Economics offer accepting that offer, either as firm or insurance. Females are as likely as males if they have an offer to accept it. Finally, we revisit the probability of enrolment into an Economics degree, conditioning on having received an offer (column 9). We find that there is no significant gender gap in enrolment in Economics at this stage. Furthermore, also conditioning on applying to an Economics degree (column 8), there is no gender gap in Economics enrolment, suggesting that the main cause of the earlier observed gender gap is the low probability of applying to Economics degrees by females. Thus, interestingly, once females decide to apply to Economics at university there is no difference in their probability of receiving offers by universities, in their

\footnotetext{
${ }^{7}$ The results are qualitatively unchanged when we add controls for popular subject combinations at A level (results not reported).
} 
own decisions to accept offers or to eventually enrol into an Economics degree. Hence, our findings underscore that the observed unconditional gender gap is due to lack of interest by females to study Economics at university which is reflected in their very low application rates.

An important underlying reason for the lack of applications by females may be related to their choice of A level subjects at high school. As Table 5 clearly shows, on average females are less likely compared to males to do Maths at A level (column 2). This might partly explain the low Economics application rates: females are less prepared to apply for an Economics degree. However, this cannot be the whole story. Even conditional on having done Maths at A level (column 4), females are less likely to apply to Economics. This suggests that what restrains females from applying for Economics degrees is not just lack of the right prerequisites for Economics degrees, in particular given that females taking Maths at A level have on average better grades than males (e.g. $46.4 \%$ get an A vs. $43.6 \%$ for males, while $25.1 \%$ get a B vs. $23.9 \%$ for males). From Table 5 it emerges that females are also less likely to do Economics at A level (column 1) and, even conditional on having done Economics at A level (column 3), females are less likely than males to apply to Economics degrees. This is consistent with a lack of interest in the subject.

To provide some more insights about the reasons behind the gender gap in Economics enrolment, Table 6 (columns 1 and 2) reports enrolment rates by gender in selected subjects. Women are more likely than men to enrol into subjects like Nursing, Social Studies other than Economics, Law, Humanities, Arts and Education, while men are more likely to enrol, beside Economics, into Math and Computer Sciences, Engineering, and Architecture. Conditioning on having done Maths at A level (columns 3 and 4) or Economics at A level (columns 7 and 8), the subject choice varies, but this general pattern of gender differences persists.

Thus, we do find evidence that females are less likely than males to do Maths at A level, an important requisite to enrol in Economics, but, even conditional on having done Maths at A level, women are less likely to enrol in Economics. This points to an important role of differences in "tastes". The range of skills that are necessary to enrol into and to successfully complete an Economics degree goes beyond having done Maths at A level, so we cannot exclude that those required skills might be different across genders. Moreover, differences in tastes may play an important role also in the choice of A level subjects at high school. Therefore, we cannot disentangle the effects of skills and preferences. It is of interest, however, to point out that the gender gap in applying to Economics is not just due to different choices in terms of A level subjects. With regards to other explanations for the gap, one possibility is, for instance, that females may dislike competition and refrain from degrees leading to competitive careers. However, looking at the application process 
for Law (Table 7), arguably a degree giving access to remunerative and competitive jobs, we see a mirror pattern compared to Economics, with females more likely to apply, while no difference emerges in the rest of the process.

\subsection{Discussion}

A better understanding of the origin of gender differences in enrolment patterns can emerge by analysing the enrolment process as a whole, accounting for a whole range of subjects, and by linking enrolment into different subjects to various labour market outcomes. This is what we do in Tonin and Wahba (2014), where we find that females are also less likely to apply to STEM (Science, Technology, Engineering and Maths) degrees at university. Perhaps, lack of Maths preparation at earlier stages creates a hurdle for females who are less encouraged to pursue Maths and Science subjects at A level and leads to loss of confidence and interest in those subjects, and in turn lower applications by females to study Economics or STEM degrees at university.

The literature has also proposed other possible explanations behind the reluctance of females to undertake Economics studies. One possibility is the lack of role models due to the scarcity of women on Economics faculties. In a study of three US Universities, Canes and Rosen (1995) find, however, no evidence that an increase in the share of women on a department's faculty led to an increase in its share of female majors. Given the choice analysed here, taking place while in high school, this is even less likely to be an explanation. Of course, role models outside of university faculties, for instance within the realm of politics and businesses or within the household, may play a more important role. Another possibility is that labour market returns matter for subject choice and that these differ, or are perceived to differ, across genders. Arcidiacono, Hotz, and Kang (2012) survey students about expected earnings both in the major they have chosen and in counterfactual majors and find that these are important factors in the choice of college major. Beyond economic returns, gender differences in career expectations and aspirations may also be important (Chevalier, 2007). We cannot discriminate among these different hypotheses or evaluate their relative importance. Our evidence only points to the fact that female students are less likely to apply for a bachelor's degree in Economics. 


\section{Concluding Remarks}

In this paper we have exploited a large administrative data set to investigate where in the application process the gender gap emerges in terms of enrolment for a bachelor's degree in Economics. What we found is that there is no evidence of universities discriminating against female applicants or of female applicants being less likely to accept an offer made by an university. The gap emerges at the application stage, with female students less likely to apply for Economics degrees to start with. This is the case even if, as argued in the introduction, Economics degrees give access to occupations that pay relatively well and to positions of influence in the policy making process. Females tend instead to apply to degrees like Nursing and Education, associated with more female concentrated occupations.

Our analysis also highlights a gap in terms of girls' preparation in high school, as measured by their choice of Maths as A level subject. Goldin, Katz, and Kuziemko (2006) found a similar pattern for the US in the late 50s, with boys taking far more Maths and Science courses in high school than girls (4.02 semesters of Maths for boys compared with 2.89 semesters for girls), however they found that in subsequent years "[g]irls gained substantially on boys in taking Science and Maths courses essentially reaching parity in 1992" and that this had a positive effect on female college completion rate. This parity does not seem to hold for the UK. Interestingly, Guiso, Monte, Sapienza, and Zingales (2008) find a positive correlation between gender equality and the gender gap in Mathematics, showing that the gap disappears in more gender-equal societies. In particular, they use Maths scores for 15-years old from the Programme for International Student Assessment (PISA), where girls' Maths scores are on average lower than those of boys, and correlate them to several measures of gender equality, like the Gender Gap Index developed by the World Economic Forum $^{8,9}$. This suggests that cultural rather than biological factors are behind the observed gender gap in Mathematics and that a positive loop may develop, with more equality leading to better educational achievement by girls, leading in turn to more equality. Even if numeracy in itself may be just one of the several factors behind the enrolment gap in Economics, we believe that enrolment into Economics may be an important channel in this loop, with girls more proficient in Maths more likely to enrol into an Economics degree and, in turn, more likely to get access to positions of

\footnotetext{
${ }^{8}$ In the last report (World Economic Forum, 2013), the score for the UK for this index was 0.744 (on an unitary scale where a higher number indicates more equality), positioning the country 18th out of 136 countries.

${ }^{9}$ Also Correll (2001) develops and finds empirical support for the hypothesis that cultural beliefs about differences in mathematical ability across genders affect individuals' assessment of their own mathematical competence and, in turn, career-relevant decisions like enroling in high school calculus and selecting a quantitative college major. Campa et al. (2011) show the importance of both firms' and individuals' attitudes in explaining the gender gap in employment.
} 
influence in policy making and in the economic life, from where they can promote a more gender equal society. 


\section{References}

[1] Arcidiacono, Peter, V. Joseph Hotz, and Songman Kang, (2012), "Modeling college major choices using elicited measures of expectations and counterfactuals", Journal of Econometrics $166.1,3-16$.

[2] British Medical Association Equal Opportunities Committee. (2009), "Equality and diversity in UK medical schools", BMA Marketing \& Publications, London.

[3] Burgoon, B. A., and M. J. Hiscox. (2009) "The Gender Divide over International Trade: Why Do Men and Women Have Different Views about Openness to the World Economy." Working paper.

[4] Campa, Pamela. (2011) "Gender quotas, female politicians and public expenditures: quasiexperimental evidence." Working Paper.

[5] Campa, Pamela, Alessandra Casarico, and Paola Profeta. (2011), "Gender culture and gender gap in employment." CESifo Economic Studies 57.1, 156-182.

[6] Canes, Brandice J., and Harvey S. Rosen. (1995), "Following in her footsteps? Faculty gender composition and women's choices of college majors." Industrial and labor relations review, 486-504.

[7] Chattopadhyay, Raghabendra, and Esther Duflo. (2004), "Women as policy makers: Evidence from a randomized policy experiment in India." Econometrica 72.5, 1409-1443.

[8] Chevalier, Arnaud. "Education, Occupation and Career Expectations: Determinants of the Gender Pay Gap for UK Graduates." (2007), Oxford Bulletin of Economics and Statistics $69.6,819-842$.

[9] Clots-Figueras, Irma. (2011), "Women in politics: Evidence from the Indian States." Journal of Public Economics 95.7, 664-690.

[10] Correll, Shelley J. (2001), "Gender and the Career Choice Process: The Role of Biased SelfAssessments." American Journal of Sociology 106.6, 1691-1730.

[11] Dynan, Karen E., and Cecilia Elena Rouse. (1997), "The underrepresentation of women in economics: A study of undergraduate economics students." The Journal of Economic Education $28.4,350-368$. 
[12] Ferreira, Fernando, and Joseph Gyourko. (2014), "Does gender matter for political leadership? The case of US mayors", Journal of Public Economics, 112, 24-39.

[13] Filippin, Antonio and Paolo Crosetto. (2014), "A reconsideration of gender differences in risk attitudes," Working Papers 2014-01, Grenoble Applied Economics Laboratory (GAEL).

[14] Goldin, Claudia, Lawrence F. Katz, and Ilyana Kuziemko. (2006), "The Homecoming of American College Women: The Reversal of the College Gender Gap." The Journal of Economic Perspectives 20.4, 133.

[15] Guiso, Luigi, Ferdinando Monte, Paola Sapienza, and Luigi Zingales. (2008), "Culture, gender, and math." Science 320, 5880, 1164.

[16] Gunderson, M. (1989), "Male-female wage differentials and policy responses", J. Econ. Lit. $27,46-72$.

[17] Machin, Stephen, and Patrick A. Puhani. (2003), "Subject of degree and the gender wage differential: evidence from the UK and Germany." Economics Letters 79.3, 393-400.

[18] May, Ann Mari, Mary G. McGarvey, and Robert Whaples. (forthcoming), "Are Disagreements Among Male And Female Economists Marginal At Best?: A Survey Of AEA Members And Their Views On Economics And Economic Policy." Contemporary Economic Policy.

[19] McDonald, Judith A., and Robert J. Thornton. (2007), "Do new male and female college graduates receive unequal pay?" Journal of Human Resources 42.1, 32-48.

[20] Moss-Racusin, Corinne A., John F. Dovidio, Victoria L. Brescoll, Mark J. Graham, and Jo Handelsman (2012), "Science faculty's subtle gender biases favor male students." Proceedings of the National Academy of Sciences 109.41, 16474-16479.

[21] O'Leary, Nigel C., and Peter J. Sloane. (2005), "The return to a university education in Great Britain." National Institute Economic Review 193.1, 75-89.

[22] Persson, Torsten, and Guido Tabellini. (2002), Political economics: explaining economic policy. MIT press.

[23] Jonung, Christina, and Ann-Charlotte Stahlberg. (2012), "Reaching the top? On gender balance in the Economics profession." Econ Journal Watch 5.2, 174-192.

[24] Kahn, Shulamit. (1995), "Women in the economics profession." The Journal of Economic Perspectives 9.4, 193-206. 
[25] Svaleryd, Helena. (2009), "Women's representation and public spending." European Journal of Political Economy 25.2, 186-198.

[26] Tonin, Mirco, and Jackline Wahba. (2014), "The cost of undershooting in degree choice", University of Southampton, mimeo.

[27] Turner, Sarah E., and William G. Bowen. (1998), "Choice of major: The changing (unchanging) gender gap." Indus. \& Lab. Rel. Rev. 52, 289.

[28] World Economic Forum. (2013), "The global gender gap report 2013." 
Table 1: Characteristics of Students Enroled for University Degrees Through UCAS in 2008/09

\begin{tabular}{lrccc}
\hline & & $\begin{array}{c}\text { All Degrees } \\
(1)\end{array}$ & $\begin{array}{c}\text { Economics Degree } \\
(2)\end{array}$ & $\begin{array}{c}\text { P-Value } \\
(3)\end{array}$ \\
\hline Individual Characteristics & $\begin{array}{r}\text { Female } \\
\text { Age Groups } \\
<20 \text { years }\end{array}$ & 57.01 & 27.43 & 0.00 \\
& & 81.36 & 95.07 & 0.00 \\
Ethnic Origin & & & \\
& White & 79.40 & 63.30 & 0.00 \\
Asian & 9.56 & 23.30 & 0.00 \\
Black & 5.76 & 7.00 & 0.01 \\
Mixed & 3.12 & 3.50 & 0.28 \\
& 2.16 & 2.91 & 0.01
\end{tabular}

\section{Socio-Economic Group}

Higher managerial and professional occup. Intermediate occupations

Lower managerial and professional occup. Lower supervisory and technical occup.

Routine occupations Semi-routine occupations

Small employers and own account workers Unknown

16.14

11.55

23.43

3.48

5.07

13.37

5.97

20.99

9.13

18.21

7.57

18.17

37.08

Sixth Form College

State exc Grammar

\section{A Level Subjects}

Economics A level Economics AS level

Math A level

Math AS level

Science A level

Science AS level

Tariff
Russell
2.77
0.10
13.62
2.51
28.24
4.63
221.4
24.08

25.20

12.56

24.57

2.91

3.50

8.34

6.15

16.77

24.06

5.90

13.61

17.78

36.28

62.37

1.70

53.60

5.14

32.28

9.78

0.00

0.12

0.19

0.12

0.00

0.00

0.70

0.00

0.00

0.00

0.00

0.62

0.42

\begin{tabular}{ccc}
\hline Number of Observations & 185002 & 2373 \\
\hline \hline
\end{tabular}

Notes: All numbers in col. 1 and 2, except for Tariff, are \%.

P-value reports the results of a t-test of Ho: All Degrees=Economics Degree.

Russell indicate enrolment in a university belonging to the Russell Group. 
Female

P-Value

(1)

(3)

Apply to Economics Degree

3.78

1.16

0.00

Receive Conditional offer|Applying Receive Unconditional offer|Applying

Receive an Offer|Applying

$\begin{array}{lll}76.49 & 78.29 & 0.18 \\ 11.85 & 10.27 & 0.12 \\ 86.47 & 85.60 & 0.42\end{array}$

Firm Decision|Offer

59.65

0.42

Insurance Decision|Offer

50.67

58.66

0.56

Enrol | Offer

61.28

49.70

0.57

\section{Enrol| Offer}

Unconditional

Economics A level

Economics AS level

Math A level

Math AS level

58.85

0.17

Conditional on applying to Economics Degrees

$\begin{array}{rccc}\text { Economics A level } & 53.64 & 49.2 & 0.01 \\ \text { Economics AS level } & 1.62 & 2.39 & 0.07 \\ \text { Math A level } & 43.45 & 49.35 & 0.02 \\ \text { Math AS level } & 5.24 & 5.14 & 0.01\end{array}$

Scores

\begin{tabular}{rlll} 
Tariff & 223 & 220 & 0.00 \\
Tariff | Apply to Economics & 312 & 339 & 0.00 \\
Tariff | Enrol in Economics & 346 & 388 & 0.00 \\
& & & \\
\hline
\end{tabular}

Number of Observations (Enrol in Economics)

$\begin{array}{cc}1.96 & 0.00 \\ 0.06 & 0.00 \\ 10.03 & 0.00 \\ 2.25 & 0.00\end{array}$

Notes: All numbers in col. 1 and 2, except for Tariff, are \%.

$\mathrm{P}$-value reports the results of a t-test of Ho: Male=Female.

The unit of observation is the student. Note that a student may apply to Economics in several universities. 
Table 3: Probability of University Enrolment in Economics Degree (Marginal Effects)

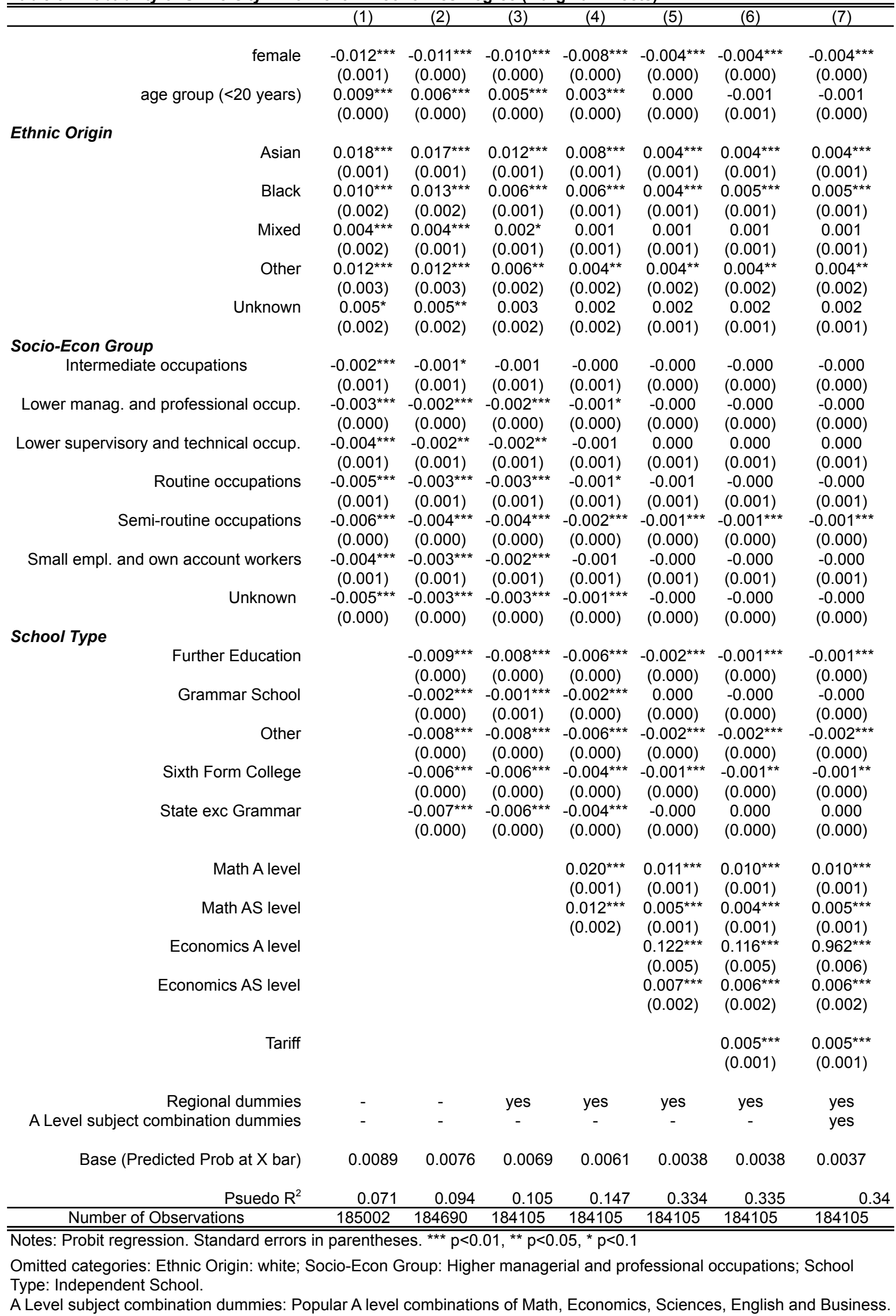


Table 4: Gender and the Application Process for Economics Degree (Marginal Effects)

\begin{tabular}{|c|c|c|c|c|c|c|c|c|c|}
\hline & $\begin{array}{l}\text { Apply } \\
\text { (1) } \\
\end{array}$ & $\begin{array}{c}\text { Cond Offer } \\
(2) \\
\end{array}$ & $\begin{array}{c}\text { Uncond Offer } \\
\text { (3) }\end{array}$ & $\begin{array}{c}\text { Offer } \\
(4) \\
\end{array}$ & $\begin{array}{c}\text { Offer } \\
(5)\end{array}$ & $\begin{array}{c}\text { Firm } \\
(6)\end{array}$ & $\begin{array}{c}\text { Insurance } \\
(7)\end{array}$ & $\begin{array}{c}\text { Enrol } \\
(8) \\
\end{array}$ & $\begin{array}{c}\text { Enrol } \\
(9)\end{array}$ \\
\hline female & $\begin{array}{c}-0.019 * * * \\
(0.001)\end{array}$ & $\begin{array}{c}0.001 \\
(0.014)\end{array}$ & $\begin{array}{l}-0.002 \\
(0.009)\end{array}$ & $\begin{array}{l}-0.013 \\
(0.011)\end{array}$ & $\begin{array}{l}-0.009 \\
(0.011)\end{array}$ & $\begin{array}{l}-0.004 \\
(0.017)\end{array}$ & $\begin{array}{l}-0.013 \\
(0.018)\end{array}$ & $\begin{array}{l}-0.018 \\
(0.017)\end{array}$ & $\begin{array}{c}-0.011 \\
(0.018)\end{array}$ \\
\hline $\begin{array}{l}\text { Base (Predicted Prob at X bar) } \\
\text { Psuedo R }{ }^{2}\end{array}$ & $\begin{array}{l}0.0141 \\
0.1048\end{array}$ & $\begin{array}{l}0.7935 \\
0.1240\end{array}$ & $\begin{array}{l}0.0850 \\
0.1660\end{array}$ & $\begin{array}{l}0.8796 \\
0.0790\end{array}$ & $\begin{array}{l}0.8830 \\
0.0920\end{array}$ & $\begin{array}{l}0.5950 \\
0.0350\end{array}$ & $\begin{array}{l}0.5010 \\
0.0390\end{array}$ & $\begin{array}{l}0.4752 \\
0.0630\end{array}$ & $\begin{array}{l}0.5301 \\
0.0590\end{array}$ \\
\hline Observations & 184105 & 4963 & 4963 & 4958 & 4958 & 4280 & 4277 & 4961 & 4280 \\
\hline
\end{tabular}

Notes: Probit regression. Standard errors in parentheses. ${ }^{* \star *} p<0.01,{ }^{* \star} p<0.05,{ }^{*} p<0.1$

Controls are age, ethnic background, socio economic background, region, and school type.

Col 1: Probability of applying to Economics degree.

Col 2: Probability of receiving a Conditional Offer, conditional on having applied.

Col 3: Probability of receiving an Unconditional Offer, conditional on having applied.

Col 4: Probability of receiving an offer (conditional or unconditional), conditional on having applied.

Col 5: Probability of receiving an offer (conditional or unconditional), conditional on having applied. Controlling for score \& A Level subjects.

Col 6: Probability of firm decision, conditional on having an offer.

Col 7: Probability of insurance decision, conditional on having an offer.

Col 8: Probability of Enrolment conditional on having applied to Economics.

Col 9: Probability of Enrolment conditional on having an Economics offer. 
Table 5: Gender Gap in A level Subjects and Conditional Applications (Marginal Effects)

\begin{tabular}{|c|c|c|c|c|c|}
\hline & $\begin{array}{c}\text { Econ A level } \\
(1) \\
\end{array}$ & $\begin{array}{c}\text { Math A level } \\
(2) \\
\end{array}$ & $\begin{array}{c}\text { Apply Econ|Econ A level } \\
(3)\end{array}$ & $\begin{array}{c}\text { Apply Econ| Math A level } \\
(4)\end{array}$ & $\begin{array}{c}\text { Apply Econ| Math \& Econ A levels } \\
(5)\end{array}$ \\
\hline female & $\begin{array}{l}-0.017^{* * *} \\
(0.001)\end{array}$ & $\begin{array}{c}-0.065^{\star * *} \\
(0.001)\end{array}$ & $\begin{array}{c}-0.083^{* * *} \\
(0.013)\end{array}$ & $\begin{array}{c}-0.027^{* * *} \\
(0.003)\end{array}$ & $\begin{array}{l}-0.036^{* * *} \\
(0.021)\end{array}$ \\
\hline Base (Predicted Prob at $\mathrm{X}$ bar) & 0.0125 & 0.0797 & 0.3458 & 0.0663 & 0.4838 \\
\hline Psuedo $\mathrm{R}^{2}$ & 0.161 & 0.166 & 0.021 & 0.049 & 0.010 \\
\hline Observations & 184105 & 184105 & 6527 & 26098 & 2782 \\
\hline
\end{tabular}

Notes: Probit regression. Standard errors in parentheses. ${ }^{* *} p<0.01,{ }^{* *} p<0.05,{ }^{*} p<0.1$

Controls are age, ethnic background, socio economic background, region, and school type.

Col 1: Probability of having done Economics A level, conditional on enrollment in university degree

Col 2: Probability of having done Maths A level, conditional on enrollment in university degree

Col 3: Probability of applying to Economics Degree, having done Economics A level

Col 4: Probability of applying to Economics Degree conditional on having done Maths A level

Col 5: Probability of applying to Economics Degree conditional on having done Maths and Economics A levels 
Table 6 : University Enrolment Rate by Gender in Selected Subjects

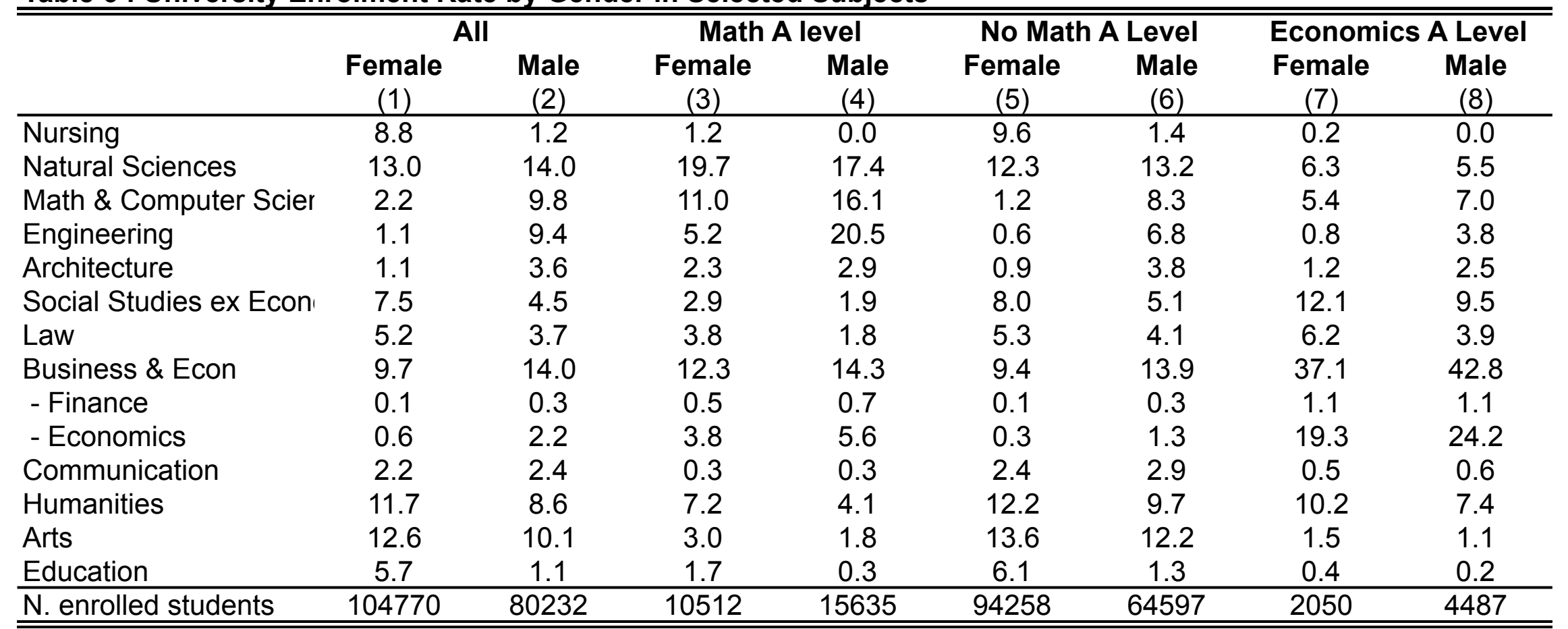

Notes: The figures are \% over the number of enroled students.

Finance and Economics are sub categories of Business \& Econ. 
Table 7: Gender and the Application Process for Law Degree (Marginal Effects)

\begin{tabular}{|c|c|c|c|c|c|c|c|c|c|}
\hline & $\begin{array}{c}\text { Enrol } \\
(1)\end{array}$ & $\begin{array}{c}\text { Enrol } \\
(2)\end{array}$ & $\begin{array}{c}\text { Apply } \\
(3)\end{array}$ & $\begin{array}{c}\text { Offer } \\
(4)\end{array}$ & $\begin{array}{c}\text { Offer } \\
(5)\end{array}$ & $\begin{array}{c}\text { Firm } \\
(6)\end{array}$ & $\begin{array}{c}\text { Insurance } \\
(7)\end{array}$ & $\begin{array}{c}\text { Enrol } \\
(8) \\
\end{array}$ & $\begin{array}{c}\text { Enrol } \\
(9)\end{array}$ \\
\hline female & $\begin{array}{r}0.015^{* * *} \\
(0.001)\end{array}$ & $\begin{array}{c}0.010^{* * *} \\
(0.001)\end{array}$ & $\begin{array}{c}0.020^{* * *} \\
(0.001)\end{array}$ & $\begin{array}{c}0.007 \\
(0.004)\end{array}$ & $\begin{array}{l}0.006 \\
(0.004)\end{array}$ & $\begin{array}{c}0.011 \\
(0.009)\end{array}$ & $\begin{array}{l}-0.005 \\
(0.010)\end{array}$ & $\begin{array}{c}0.007 \\
(0.009)\end{array}$ & $\begin{array}{l}0.003 \\
(0.009)\end{array}$ \\
\hline $\begin{array}{l}\text { Base (Predicted Prob at X bar) } \\
\text { Psuedo } \mathrm{R}^{2}\end{array}$ & $\begin{array}{c}0.04 \\
0.017\end{array}$ & $\begin{array}{c}0.04 \\
0.054\end{array}$ & $\begin{array}{c}0.06 \\
0.031\end{array}$ & $\begin{array}{c}0.94 \\
0.093\end{array}$ & $\begin{array}{l}0.94 \\
0.093\end{array}$ & $\begin{array}{c}0.73 \\
0.017\end{array}$ & $\begin{array}{c}0.54 \\
0.073\end{array}$ & $\begin{array}{c}0.64 \\
0.061\end{array}$ & $\begin{array}{c}0.67 \\
0.055\end{array}$ \\
\hline Observations & 185002 & 185002 & 185002 & 13189 & 13189 & 12111 & 12111 & 13189 & 12111 \\
\hline
\end{tabular}

Notes: Probit regression. Standard errors in parentheses. ${ }^{* \star *} p<0.01,{ }^{* *} p<0.05,{ }^{*} p<0.1$

Controls are age, ethnic background, socio economic background, region, and school type.

Col 1: Probability of enrolment (unconditional).

Col 2: Probability of enrolment (unconditional). Controlling for score \& A level subjects.

Col 3: Probability of applying to degree.

Col 4: Probability of receiving an offer (conditional or unconditional), conditional on having applied.

Col 5: As in column 4, controlling for score \& A level subjects.

Col 6: Probability of firm decision, conditional on having an offer.

Col 7: Probability of insurance decision, conditional on having an offer.

Col 8: Probability of enrolment conditional on having applied to that degree.

Col 9: Probability of enrolment conditional on having an offer. 